\title{
学習直後の項目と順序の記憶における語長効果：
}

\author{
項目と順序の過程分離手続きを用いた検討 \\ ○都賀美有紀 ${ }^{1} \cdot$ 星野祐司 ${ }^{1}$ \\ ( ${ }^{1}$ 立命館大学) \\ キーワード : 語長効果, 項目と順序の記憶, 過程分離手続き
}

\begin{abstract}
Word length effects on item and order information memory in immediate retention interval: Applying the process dissociation framework to the item/order distinction

Miyuki TOGA ${ }^{1}$ and Yuji HOSHINO ${ }^{1}$

$\left({ }^{1}\right.$ Ritsumeikan University)
\end{abstract}

Key Words: Word length effect, Item and order memory, Process dissociation

項目の記憶では学習直後に示された語長効果が遅延後も維 持されるが，順序の記憶では学習直後にのみ語長効果が示さ れることが, 学習直後と 14 秒後の自由再生課題と再構成課題 を用いた研究で報告されている（都賀・星野，2015）。項目と 順序の記憶における音韻情報の記憶の特性の違いが推測され る。しかし, 自由再生課題や再構成課題といった伝統的な保 持テストは項目と順序の記憶の両方の影響を受ける（Nairne \& Kelley, 2004)。そのため, 語長が項目および順序の記憶に どのように影響しているのかは確かではない。

Nairne \& Kelley（2004）は比較的純粋な項目の記憶と順序 の記憶を推定することを目的として項目と順序の記憶につい ての過程分離手続きのパラダイムを提案した。この手法は系 列再生課題の正答率 (CS: 項目と順序を覚えている確率) と 指定された順番の単語は回答しない制限のある自由再生課題 の誤答率 (ER: 項目は覚えているが順序を覚えていない確率) から項目を覚えている確率 $(I)$ と順序を覚えている確率 $(O)$ を算出する $(C S=I O, E R=I(1-O)$, すなわち, $I=C S+E R$, $O=C S / I)$ 。7.5 秒の遅延後の場合は, $I$ は短単語が優勢な語長 効果が示されるのに対し, $O$ には語長の影響が示されない(都 賀・星野, 2006)。学習直後については明らかではない。その ため, 本研究では学習直後の項目と順序の記憶における語長 効果を過程分離手続きのパラダイムを用いて検討する。

\section{方 法}

実験計画 語長 (短単語, 長単語) と課題 (系列再生課題, 制限された自由再生課題）の実験参加者内要因であった。

実験参加者 学生 20 名 (男性 5 名, 女性 15 名, 平均年齢 19.1 歳, $S D=0.50)$ が実験に参加した。

材料と装置 天野・近藤（1999）より文字音声単語親密度 数 5.0 から 6.5 の中から, 短単語としてモーラ数 2 および長単 語としてモーラ数 5 の単語を 100 単語ずつ選択して, ひらが な表記の 5 つの単語の短単語リストと長単語リストを各 20 リ スト作成した。単語はパーソナルコンピューターで提示した。 回答には 5 本の買線が引かれた用紙を 1 試行 1 枚使用した。

手続き 実験は個別に実施した。系列再生課題および制限 された自由生成課題ともに, $1000 \mathrm{~ms}$ の注視点の提示後，5つ の単語を無作為な順で継時的に $950 \mathrm{~ms}$ ずつ提示した（ISI は $250 \mathrm{~ms}$ )。実験参加者には単語を音読し, 単語と順序の両方を 覚えることを求めた。系列再生課題の場合は単語の学習直後 に，提示された単語を提示順通りに回答用紙の 5 本の罡線に 上から筆記するように求めた。思い出せない単語は代わりに バツ印を書くようにと教示した。制限された自由再生課題の 場合は, 単語の学習直後に赤色で 1 から 5 までのいずれかの 数字を示し，この数字の順番に提示された単語は回答せずに 代わりにバツ印を書き，それ以外の単語のみを自由な順で筆 記するように求めた。両課題とも回答時間は制限しなかった。 各課題は短単語と長単語を 10 リストずつランダムに提示し た。課題順はカウンターバランスをとった。
結 果

系列再生課題は提示単語を提示順に回答した場合を正答とし た $(C S)$ 。制限された自由再生課題は回答しない順番と指示 した単語を報告した場合を誤答とした $(E R)$ 。CS および $E R$ から $I$ と $O$, さらに項目を覚えておらず順序だけを覚えてい る確率 $(O-I O)$ を算出した。語長ごとの $C S, E R, I, O$ およ び $O$ - IO を表 1 に示した。

\begin{tabular}{ccc} 
表1 & \multicolumn{3}{c}{ 語長ごとの $C S, E R, I, O$ おびO-IO } \\
\cline { 2 - 3 } & \multicolumn{3}{c}{ 短単語 } & 長単語 \\
\hline$C S$ & 0.81 & 0.72 \\
$E R$ & 0.03 & 0.03 \\
$I$ & 0.84 & 0.74 \\
$O$ & 0.97 & 0.96 \\
$O-1 O$ & 0.15 & 0.24 \\
\hline
\end{tabular}

$C S, E R, I ， O$ および $O-I O$ のそれぞれにおいて語長につ いての $t$ 検定を行った。その結果, CS および I は短単語が長 単語よりも有意に高く $(t(19)=3.80, p<.01 ; t(19)=4.08, p$ $<.01), \mathrm{ER}$ および $\mathrm{O}$ は有意な語長の効果は示されなかった $(t$ $(19)=0.35$, ns.; $t(19)=0.82$, ns. $) 。 O-I O$ については長単語が 短単語よりも有意に高かった $(t(19)=4.15, p<.01)$ 。

\section{考 察}

本研究では, 項目の記憶の推定值 $(I)$ には語長効果が示さ れたが，項目の記憶を構成する項目は覚えているが順序を覚 えていない確率 $(E R)$ に語長効果が示されず, 語長効果が示 されたのは項目と順序の両方を覚えている確率 $(C S)$ であっ た。また，順序の記憶の推定值 $(O)$ には示されなかった。 これらから，項目を順序通りに思いだすときに語長が影響す ることが指摘できる。

順序記憶の測度として再構成課題を用いた場合に学習直後 に語長効果が示されることは (都賀・星野, 2015), 項目を順 序通りに想起する方略によるのかもしれない。ただし, 項目 の記憶と異なり遅延後の順序の記憶には語長効果が示されな いこと（都賀・星野，2006，2015）および本研究の項目を覚 えておらず順序だけを覚えている確率 $(O-I O)$ には長単語が 優勢な語長効果が示された点に, 項目と順序の記憶に音韻情 報の処理の特性の違いが示唆される。

\section{引用文献}

天野成昭・近藤公久 (1999). 日本語の語彙特性 単語親密度 三省堂

Nairne, J. S., \& Kelley, M. R. (2004). Journal of Memory and Language, 50, 113-133.

都賀美有紀 - 星野祐司 (2006). 日本認知心理学会第 4 回大会論 文集 p. 153 .

都賀美有紀 - 星野祐司 (2015). 認知心理学研究, 12, 121-128. 